\title{
Synthesis of novel cage-annnulated fluoromacrocycles
}

\author{
Alan P. Marchand,* H. K. Hariprakasha, Anna Hazlewood, Kasireddy Krishnudu, \\ Mohamed Takhi, William H. Watson,* and Satish G. Bodige \\ Department of Chemistry, University of North Texas, Denton, Texas 76203-5070 \\ Department of Chemistry, Texas Christian University, Fort Worth, Texas 76129-8860 \\ E-mail:w.watson@tcu.edu \\ E-mail:marchand@unt.edu
}

\section{Dedicated to Professor B. S. Thyagarajan on the occasion of his $70^{\text {th }}$ birthday in recognition of his many contributions to science and to humanity \\ (received 01 Mar 02; accepted 05 May 02; published on the web 13 May 02)}

\begin{abstract}
Two new cage functionalized, partially fluorinated crown ethers ( 7 and 9 ) have been synthesized. The structure of $\mathbf{7}$ has been established unequivocally via application of X-ray crystallographic methods.
\end{abstract}

Keywords: Polycarbocyclic cage molecules, fluorinated macrocyclic polyethers, host-guest chemistry

\section{Introduction}

Pedersen's ${ }^{1}$ early investigations of the host-guest chemistry of macrocyclic crown ethers has led to an explosion of interest in their use as host systems for the study of molecular recognition and inclusion phenomena. Numerous applications of crown ethers arise from their ability to enter into selective complexation with alkali metal cations and to transport these species selectively across liquid membranes. ${ }^{2,3}$

More recently, the introduction of covalently bonded fluorine into crown ethers and cryptands has attracted considerable interest worldwide. The existence of electrostatic interactions of the type C-F $\cdots \mathrm{M}^{+}$have been demonstrated both in the solid state (X-ray structure studies) ${ }^{4}$ and in solution (NMR spectroscopic studies). ${ }^{5}$ These experimental observations are supported by the results of theoretical calculations. ${ }^{6}$ The high electronegativity and hardness of fluorine $^{7}$ render covalently bonded fluorine (C-F) suitable as an electron-pair donor for complexation with hard acceptors, e.g., alkali metal (Group I) and alkaline earth (Group II) metal cations, respectively. ${ }^{8}$

Hitherto, we have demonstrated that cage-annulated crown ethers, ${ }^{9}$ cryptands, ${ }^{10}$ molecular 
clefts, ${ }^{11}$ and molecular boxes, ${ }^{12}$ constitute a new class of host systems for the study of host-guest interactions (i.e., molecular recognition and inclusion phenomena). Recently, we have undertaken the synthesis of some fluorine-containing analogs of these systems. In the present study, we report the synthesis of a fluorinated podand, 5 (Scheme 1), which subsequently has been converted into two cage-annulated, fluorine-containing crown ethers, i.e., 7 and 9 (Scheme 2).

Synthesis of fluorinated podands and crown ethers The approach employed to prepare cageannulated podand, 5 is shown in Scheme 1. This compound, which incorporates four $\mathrm{CF}_{2}$ groups into its macrocyclic framework, serves as the key precursor to cage-annulated crown ethers $\mathbf{7}$ and 9. In our hands, mono-O-benzylation of 2,2,3,3-tetrafluorobutane-1,4-diol (1) afforded 2 in 58\% isolated yield. Subsequent base promoted reaction of 2 (2 equivalents) with 3,5-bis(2'tosyloxyethyl)-4-oxahexacyclo[5.4.1. $0^{2,6} \cdot 0^{3,10} \cdot 0^{5,9} \cdot 0^{8,11}$-dodecane (3) ${ }^{13}$ produced 4 (62\% yield). Finally, hydrogenolysis of $\mathbf{4}$ resulted in removal of the two $O$-benzyl protecting groups in $\mathbf{4}$ with concomitant formation of the desired podand, 5 (Scheme 1), in 90\% yield.

With podand 5 in hand, its conversion into the corresponding cage-annulated crown ethers cage-annulated crown ethers 7 and $\mathbf{9}$ could be accomplished readily by using the approach outlined in Scheme 2. Thus, base promoted reaction of 5 with 2,6-bis(bromomethyl)pyridine (6) ${ }^{14}$ produced the corresponding crown ether, 7 , in $62 \%$ yield. Similarly, base promoted reaction of 5 with 2,6-bis(bromomethyl)-1-fluorobenzene (8) ${ }^{15}$ afforded crown ether 9 (62\% yield; see the Experimental Section).

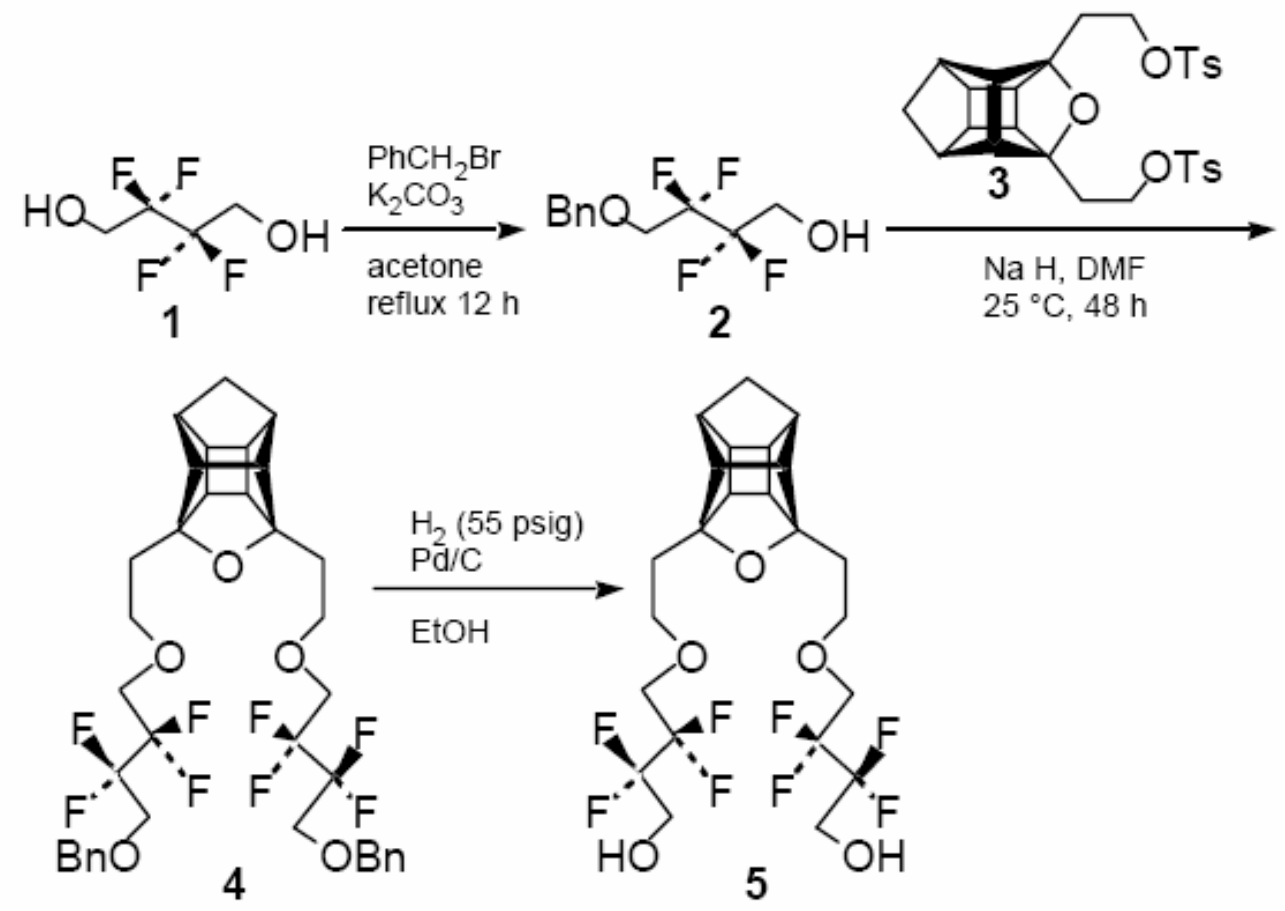

\section{Scheme 1}



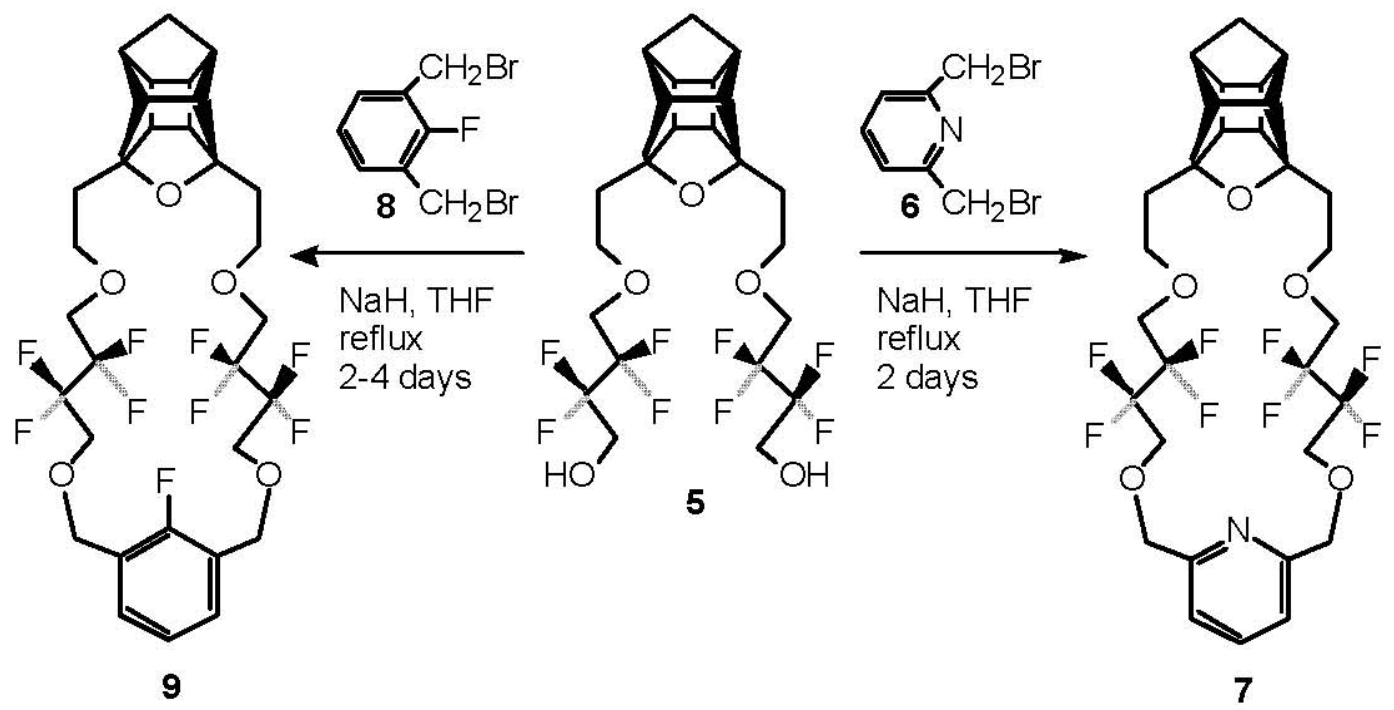

Scheme 2

\section{X-Ray crystal structure of 7}

The structure of crown ether 7 was established unequivocally via application of X-ray crystallographic methods. A structure drawing of 7 is shown in Figure 1. Inspection pf the structure drawing reveals that incorporation of a 3,5-difunctionalized oxahexacyclic cage moiety and a 2,6-disubstituted pyridine ring into the macrocyclic backbone confers a measure of rigidity upon the crown ether and thereby provides a degree of preorganization to the resulting cavity. In addition, it should be noted that the cage moiety serves as a lipophilic component, thereby reducing the solubility of cage containing crown ethers in water and assisting in its recovery via extraction into a nonpolar medium.

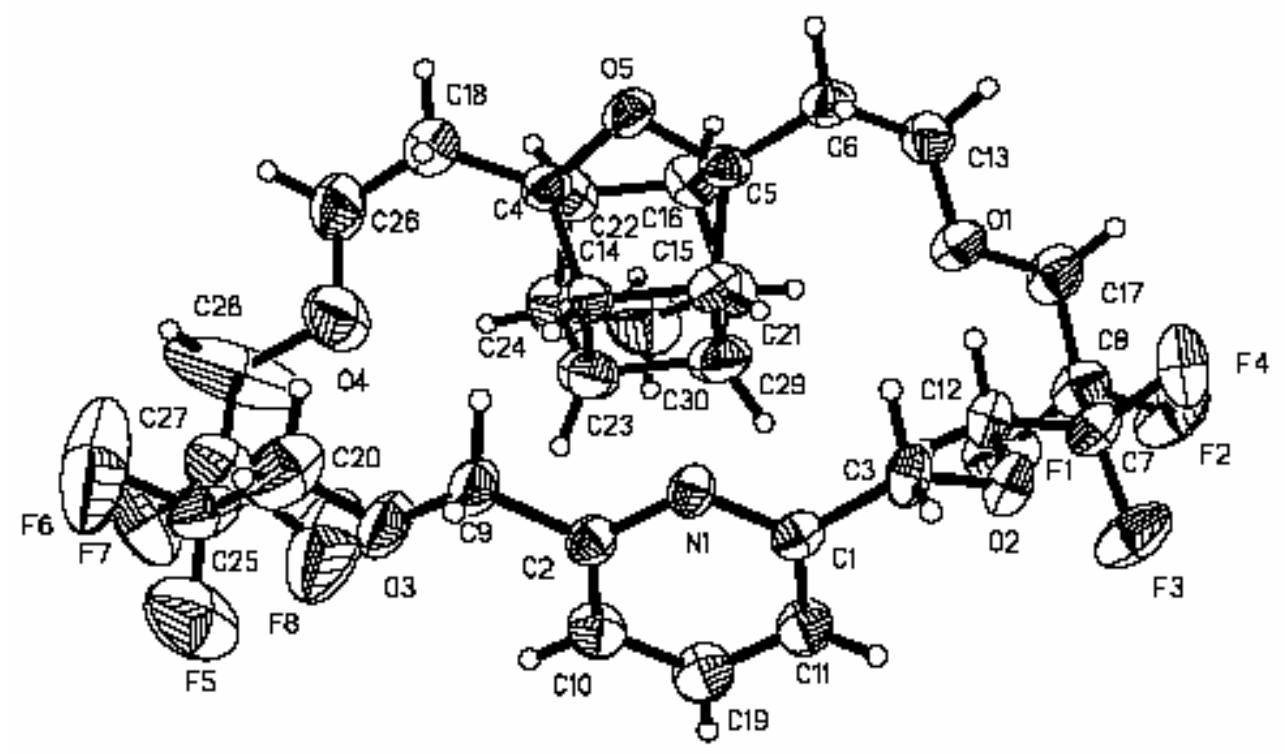

Figure 1. X-ray structure drawing of 7. 


\section{Results of alkali metal picrate extraction experiments}

Alkali metal picrate extraction experiments were performed by using a previously published procedure $^{16}$ with 7 and 9 as hosts in a chloroform-water binary solvent system. The results thereby obtained, shown in Table 1, are compared with the corresponding results obtained for two previously studied model systems, i.e., 18-crown- 6 and a cage annulated host, $\mathbf{1 0}^{17}$, that serves as a structural analog of 7. The data in Table 1 indicate that $\mathbf{7 , 9}$, and $\mathbf{1 0}$ are inefficient alkali metal cation complexants relative to 18-crown-6.

Table 1. Alkali metal picrate extraction data

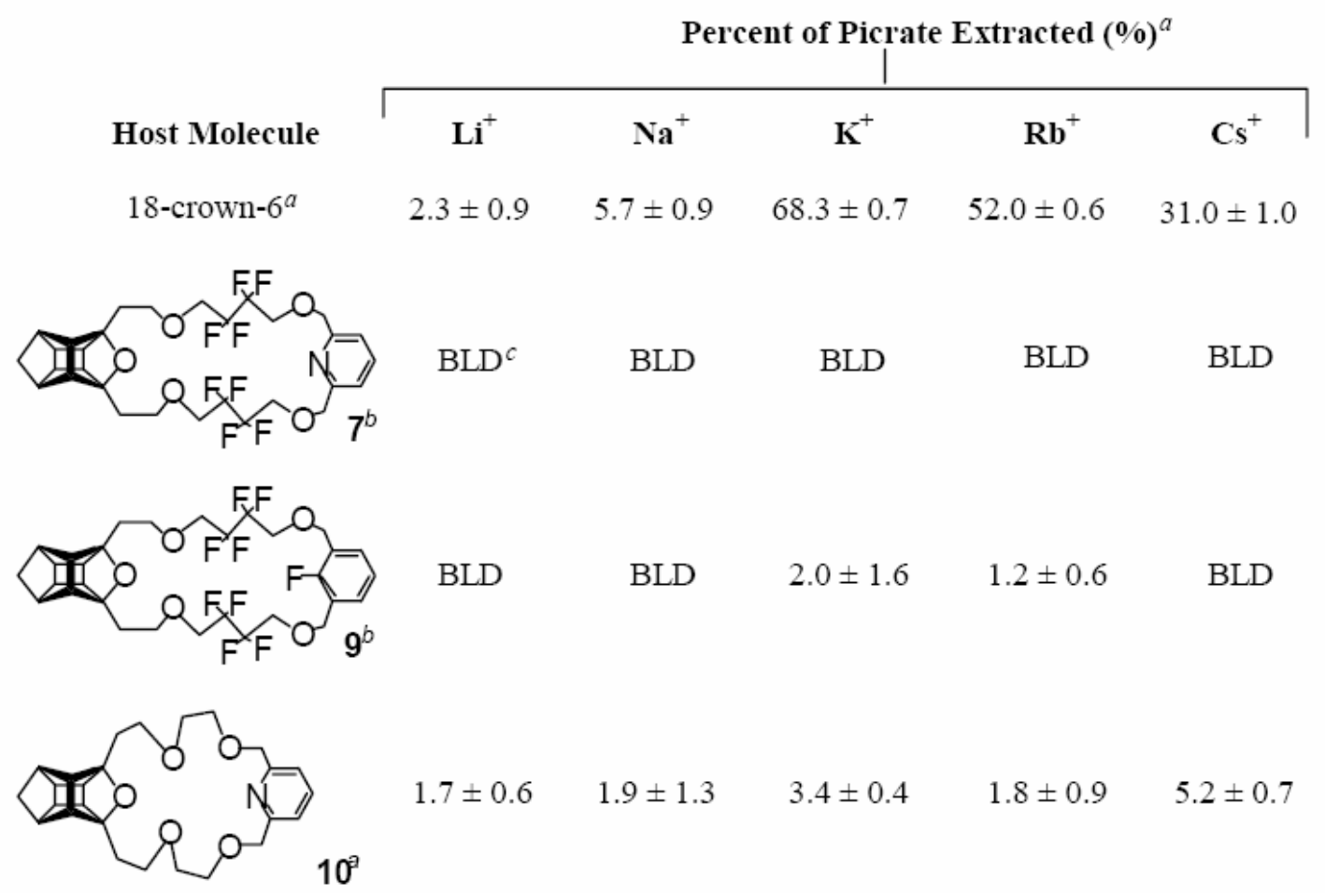

${ }^{a}$ Averages and standard deviations calculated for data obtained from three independent extraction experiments; see reference $17 .{ }^{b}$ Averages and standard deviations calculated for data obtained from six independent extraction experiments. ${ }^{c} \mathrm{BLD}=$ Below limit of detection.

Other investigators ${ }^{5}$ have observed characteristic changes in ${ }^{1} \mathrm{H},{ }^{13} \mathrm{C}$, and ${ }^{19} \mathrm{~F}$ NMR spectra of complexes between fluorinated hosts and metal cation guests that provide clear evidence for the importance of C-F $\cdots \mathrm{M}^{+}$interactions in the systems that they studied. However, it should be noted that many of the reported examples involve fluorinated cages that contain a highly preorganized, nearly cyclic array of several C-F bonds that are capable of binding tightly to a metal cation guest via multiple $\mathrm{C}-\mathrm{F} \cdots \mathrm{M}^{+}$interactions. The lack of similar preorganization of the $\mathrm{C}-\mathrm{F}$ bonds present in cage-annulated crown ethers 7 and 9 relative, e.g., to the types of fluorinated cage hosts studied by Takemura and coworkers ${ }^{5 b, 5 \mathrm{c}}$ may account for the relatively poor efficiencies that we observed when we attempted to employ $\mathbf{7}$ and $\mathbf{9}$ as alkali metal cation complexants 
and/or extractants.

\section{Summary and Conclusions}

Two novel cage-annulated, fluorine-containing crown ethers, i.e., $\mathbf{7}$ and $\mathbf{9}$, have been prepared via an efficient synthesis that employs commercially available 2,2,3,3-tetrafluorobutane-1,4-diol. The structure of one of these crown ethers, i.e., 7, has been established unequivocally via application of X-ray crystallographic techniques. The results of alkali metal picrate extraction experiments suggest that neither $\mathbf{7}$ nor $\mathbf{9}$ is capable of functioning efficiently as an alkali metal cation extractant in solution.

\section{Experimental Section}

General Procedures. Melting points are uncorrected. Elemental microanalytical data were obtained by personnel at M-H-W Laboratories, Phoenix, AZ. High-resolution mass spectral data reported herein were obtained at the Mass Spectrometry Facility at the Department of Chemistry and Biochemistry, University of Texas at Austin by using a ZAB-E double sector high-resolution mass spectrometer (Micromass, Manchester, England) that was operated in the chemical ionization mode. Tetramethylsilane was used as internal standard for ${ }^{1} \mathrm{H}$ and ${ }^{13} \mathrm{C}$ NMR and $\mathrm{CFCl}_{3}$ for ${ }^{19} \mathrm{~F}$ NMR.

Preparation of 2. A mixture of 2,2,3,3-tetrafluorobutane diol 1 (4.86 g, $30 \mathrm{mmol}), \mathrm{K}_{2} \mathrm{CO}_{3}(12.6$ $\mathrm{g}, 91.2 \mathrm{mmol})$, and benzyl chloride $(3.12 \mathrm{~g}, 24 \mathrm{mmol})$ in acetone $(100 \mathrm{~mL})$ was refluxed for $12 \mathrm{~h}$, at which time the external heat source was removed, and the reaction mixture was allowed to cool gradually to ambient temperature. The reaction mixture was filtered through a pad of Celite, and the residue was washed with EtOAc $(50 \mathrm{~mL})$. The filtrate was concentrated in vacuo, and the residue was purified via column chromatography on silica gel by using 15\% EtOAc-hexane as eluent. Pure 2 (4.66 g, 58\%) was thereby obtained as a colorless, viscous oil: IR (film) 3345 (br), 2962 (m), 2847 (w), 1622 (m), 1439 (s), 1176 (m), $790 \mathrm{~cm}^{-1}(\mathrm{~m}) ;{ }^{1} \mathrm{H}$ NMR $\left(\mathrm{CDCl}_{3}\right): \delta 2.78$ (br s, peak disappears when sample is shaken with a few drops of $\left.\mathrm{D}_{2} \mathrm{O}, 1 \mathrm{H}\right), 3.80-4.10(\mathrm{~m}, 4 \mathrm{H}), 4.78$ $(\mathrm{s}, 2 \mathrm{H}), 7.29-7.45(\mathrm{~m}, 5 \mathrm{H}) ;{ }^{13} \mathrm{C} \mathrm{NMR}\left(\mathrm{CDCl}_{3}\right) \delta 60.6\left(\mathrm{t}, J_{\mathrm{CF}}=27.1 \mathrm{~Hz}\right), 66.8\left(\mathrm{t}, J_{\mathrm{CF}}=27.9 \mathrm{~Hz}\right)$, $74.6(\mathrm{t}), 116.5\left(\mathrm{tt}, J_{\mathrm{CF}}=251.4,30.1 \mathrm{~Hz}\right), 116.6\left(\mathrm{tt}, J_{\mathrm{CF}}=252.0,30.8 \mathrm{~Hz}\right), 128.4(\mathrm{~d}), 128.9(\mathrm{~d})$, 129.1 (d), 136.6 (s). ${ }^{19} \mathrm{~F}-\mathrm{NMR}\left(\mathrm{CDCl}_{3}\right) \delta$-124.8, -122.2. Exact Mass (CI-HRMS) Calcd. for $\mathrm{C}_{11} \mathrm{H}_{12} \mathrm{~F}_{4} \mathrm{O}_{2}:[\mathrm{Mr}+1]^{+} \mathrm{m} / \mathrm{z} 252.07734$. Found: $[M \mathrm{r}+1]^{+} \mathrm{m} / \mathrm{z} 252.07707$.

Preparation of 4. A suspension of $\mathrm{NaH}(1.18 \mathrm{~g}$ of a $60 \%$ dispersion of $\mathrm{NaH}$ in minearl oil, 29.1 mmol) in dry DMF $(30 \mathrm{~mL})$ under argon was cooled to $0{ }^{\circ} \mathrm{C}$ via application of an external icewater bath. To this cooled suspension was added with stirring a solution 2 (2.88 $\mathrm{g}, 11.4 \mathrm{mmol})$ in dry DMF $(70 \mathrm{~mL})$, and the resulting mixture was allowed to warm gradually to ambient 
temperature while stirring during $2 \mathrm{~h}$. The external ice-water bath again was applied, and the mixture was cooled to $0{ }^{\circ} \mathrm{C}$. To the cooled reaction mixture was was added a solution of $3^{13}$ (3.6 $\mathrm{g}, 7.5 \mathrm{mmol})$ in DMF $(15 \mathrm{~mL})$. The resulting mixture was allowed to warm gradually to ambient temperature with stirring during $24 \mathrm{~h}$. The reaction mixture was concentrated in vacuo to remove DMF. The residue was dissolved in $\mathrm{CHCl}_{3}(100 \mathrm{~mL})$, and the resulting solution was washed sequentially with water $(80 \mathrm{~mL})$ and with brine $(80 \mathrm{~mL})$. The organic layer was dried $\left(\mathrm{MgSO}_{4}\right)$ and filtered, and the filtrate was concentrated in vacuo. The residue was purified via column chromatography on silica gel by using $20 \%$ EtOAc-hexane as eluent. Pure $4(2.87 \mathrm{~g}, 62 \%)$ was thereby obtained as a colorless, viscous oil: IR (film) 2947 (m), 2860 (m), 2370 (m), 1643 (s), $1430(\mathrm{w}), 1132(\mathrm{~s}), 925 \mathrm{~cm}^{-1}(\mathrm{w}) ;{ }^{1} \mathrm{H} \mathrm{NMR}\left(\mathrm{CDCl}_{3}\right) \delta 1.51(\mathrm{AB}, J \mathrm{AB}=10.2 \mathrm{~Hz}, 1 \mathrm{H}), 1.75(\mathrm{AB}$, $\left.J_{\mathrm{AB}}=10.2 \mathrm{~Hz}, 1 \mathrm{H}\right), 1.98-2.21(\mathrm{~m}, 4 \mathrm{H}), 2.36-2.71(\mathrm{~m}, 8 \mathrm{H}), 3.55-3.72(\mathrm{~m}, 4 \mathrm{H}), 3.75-4.05(\mathrm{~m}, 8$ $\mathrm{H}), 4.65(\mathrm{~s}, 4 \mathrm{H}), 7.20-7.45(\mathrm{~m}, 10 \mathrm{H}) ;{ }^{13} \mathrm{C}$ NMR $\left(\mathrm{CDCl}_{3}\right) \delta 33.0(\mathrm{t}), 42.1(\mathrm{~d}), 43.9(\mathrm{t}), 44.8(\mathrm{~d})$, $48.8(\mathrm{~d}), 59.3(\mathrm{~d}), 67.3\left(\mathrm{t}, J_{\mathrm{CF}}=25.1 \mathrm{~Hz}\right), 68.3\left(\mathrm{t}, J_{\mathrm{CF}}=25.3 \mathrm{~Hz}\right), 70.4(\mathrm{t}), 74.8(\mathrm{t}) 94.6(\mathrm{~s}), 116.6$ (tt, $\left.J_{\mathrm{CF}}=251.8 \mathrm{~Hz}, J_{\mathrm{CF}}^{\prime}=31.1 \mathrm{~Hz}\right), 116.8\left(\mathrm{tt}, J_{\mathrm{CF}}=252.1 \mathrm{~Hz}, J_{\mathrm{CF}}^{\prime}=30.8 \mathrm{~Hz}\right), 128.2(\mathrm{~d}), 128.5$ (d), 129.0 (d), 137.3 (s); ${ }^{19} \mathrm{~F}$ NMR $\left(\mathrm{CDCl}_{3}\right) \delta$-124.7, -122.1. CI-HRMS Calcd for $\mathrm{C}_{37} \mathrm{H}_{40} \mathrm{~F}_{8} \mathrm{O}_{5}$ : $[\mathrm{Mr}+\mathrm{H}]^{+} \mathrm{m} / \mathrm{z}$ 717.2826, Found: $\mathrm{m} / \mathrm{z}$ 717.2829.

Preparation of 5. To a solution of $4(4.0 \mathrm{~g}, 5.6 \mathrm{mmol})$ in $\mathrm{EtOH}(150 \mathrm{~mL})$ was added palladized charcoal ( $0.35 \mathrm{~g}$, catalytic amount), and the resulting mixture was reacted with $\mathrm{H}_{2}$ (55 psig) on a Parr shaker apparatus during 3 days. The reaction mixture was filtered through a pad of Celite, and the residual filter cake was washed sequentially with $\mathrm{EtOH}(50 \mathrm{~mL})$ and EtOAc $(50 \mathrm{~mL})$. The filtrate was concentrated in vacuo, and the residue was purified via column chromatography on silica gel by using EtOAc as eluent. Pure $5(2.7 \mathrm{~g}, 90 \%)$ was thereby obtained as a colorless viscous oil; IR (film) 3313 (br, s), 2970 (m), 2842 (w), 1465 (m), 1102 (s), 1028 (w), $902 \mathrm{~cm}^{-1}$ (w); ${ }^{1} \mathrm{H}$ NMR $\left(\mathrm{CDCl}_{3}\right) \delta 1.51\left(\mathrm{AB}, J_{\mathrm{AB}}=10.6 \mathrm{~Hz}, 1 \mathrm{H}\right), 1.85\left(\mathrm{AB}, J_{\mathrm{AB}}=10.6 \mathrm{~Hz}, 1 \mathrm{H}\right), 2.05(\mathrm{t}, J$ $=6.6 \mathrm{~Hz}, 4 \mathrm{H}), 2.31-2.71(\mathrm{~m}, 8 \mathrm{H}), 3.55(\mathrm{br} \mathrm{s}, 2 \mathrm{H}), 3.66(\mathrm{t}, J=6.6 \mathrm{~Hz}, 4 \mathrm{H}), 3.81(\mathrm{t}, J=13.1$ $\mathrm{Hz}, 4 \mathrm{H}), 3.90(\mathrm{t}, J=13.1 \mathrm{~Hz}, 4 \mathrm{H}) ;{ }^{13} \mathrm{C} \mathrm{NMR}\left(\mathrm{CDCl}_{3}\right) \delta 31.8(\mathrm{t}), 41.3(\mathrm{~d}), 43.1(\mathrm{t}), 44.1(\mathrm{~d}), 47.8$ $(\mathrm{d}), 58.25(\mathrm{~d}), 59.9\left(\mathrm{t}, J_{\mathrm{CF}}=27.1 \mathrm{~Hz}\right), 67.5\left(\mathrm{t}, J_{\mathrm{CF}}=27.1 \mathrm{~Hz}\right), 69.5(\mathrm{t}), 94.5(\mathrm{~s}), 115.8\left(\mathrm{tt}, J_{\mathrm{CF}}=\right.$ $\left.251.8 \mathrm{~Hz}, J_{\mathrm{CF}}^{\prime}=30.6 \mathrm{~Hz}\right), 115.9\left(\mathrm{tt}, J_{\mathrm{CF}}=251.7 \mathrm{~Hz}, J_{\mathrm{CF}}^{\prime}=30.7 \mathrm{~Hz}\right),{ }^{19} \mathrm{~F} \mathrm{NMR}\left(\mathrm{CDCl}_{3}\right) \delta-124.8$, -122.6. CI-HRMS Calcd. for $\mathrm{C}_{23} \mathrm{H}_{28} \mathrm{~F}_{8} \mathrm{O}_{5}:[\mathrm{Mr}+\mathrm{H}]^{+} \mathrm{m} / \mathrm{z}$ 537.1887. Found: $\mathrm{m} / \mathrm{z}$ 537.1865.

Preparation of 7. A suspension of $\mathrm{NaH}$ ( $37 \mathrm{mg}$ of a $60 \%$ suspension of $\mathrm{NaH}$ in mineral oil, 0.77 $\mathrm{mmol})$ in dry THF $(5 \mathrm{~mL})$ under argon was cooled to $0{ }^{\circ} \mathrm{C}$ via application of an external icewater bath. To this cooled solution was added dropwise with stirring a solution of 5 (168 $\mathrm{mg}$, $0.259 \mathrm{mmol})$ in dry THF $(10 \mathrm{~mL})$ under argon. After the addition of 5 had been completed, the external ice-water bath was removed, and the reaction mixture was allowed to warm gradually to ambient temperature while stirring during $2 \mathrm{~h}$. To the resulting mixture was added dropwise with stirring a solution of 2,5-bis(bromomethyl)pyridine $\left(6,{ }^{14} 66 \mathrm{mg}, 0.259 \mathrm{mmol}\right)$ in dry THF (10 $\mathrm{mL}$ ). After the addition of $\mathbf{6}$ had been completed, the reaction mixture was refluxed during 2 days, at which time the reaction mixture was cooled to $0{ }^{\circ} \mathrm{C}$ via application of an external icewater bath, and the reaction was quenched via careful, dropwise addition of cold water $(2 \mathrm{~mL})$ with stirring. The resulting mixture was concentrated in vacuo, and the residue was extracted into 
EtOAc $(100 \mathrm{~mL})$. The organic phase was washed sequentially with water $(70 \mathrm{~mL})$ and brine $(80$ $\mathrm{mL})$, dried $\left(\mathrm{MgSO}_{4}\right)$, and filtered, and the filtrate was concentrated in vacuo. The residue was purified via column chromatography on silica gel by eluting with $20 \%$ EtOAc-hexane. Pure 7 (124 mg, 62\%) was thereby obtained as a colorless microcrystalline solid: $\mathrm{mp} 114-115{ }^{\circ} \mathrm{C}$; IR (film) $2950(\mathrm{~s}), 1618(\mathrm{w}), 1496(\mathrm{~m}), 1150(\mathrm{~m}), 435 \mathrm{~cm}^{-1}(\mathrm{~s}) ;{ }^{1} \mathrm{H} \mathrm{NMR}\left(\mathrm{CDCl}_{3}\right) \delta 1.48\left(\mathrm{AB}, J_{\mathrm{AB}}=\right.$ $12.2 \mathrm{~Hz}, 1 \mathrm{H}), 1.81\left(\mathrm{AB}, J_{\mathrm{AB}}=12.2 \mathrm{~Hz}, 1 \mathrm{H}\right), 2.01(\mathrm{t}, J=6.1 \mathrm{~Hz}, 4 \mathrm{H}), 2.25-2.55(\mathrm{~m}, 8 \mathrm{H}), 3.50-$ $3.70(\mathrm{~m}, 4 \mathrm{H}), 3.82$ (t, $J=14.2 \mathrm{~Hz}, 4 \mathrm{H}), 4.04(\mathrm{t}, J=14.4 \mathrm{~Hz}, 4 \mathrm{H}), 4.78(\mathrm{~s}, 4 \mathrm{H}), 7.38(\mathrm{~d}, J=6.2$ $\mathrm{Hz}, 2 \mathrm{H}), 7.75(\mathrm{t}, J=8.1 \mathrm{~Hz}, 1 \mathrm{H}) ;{ }^{13} \mathrm{C} \mathrm{NMR}\left(\mathrm{CDCl}_{3}\right) \delta 32.4(\mathrm{t}), 41.6(\mathrm{~d}), 43.4(\mathrm{t}), 44.3(\mathrm{~d}), 48.3$ $(\mathrm{d}), 58.8(\mathrm{~d}), 68.0\left(\mathrm{t},\left(\mathrm{t}, J_{\mathrm{CF}}=25.3 \mathrm{~Hz}\right), 68.5\left(\mathrm{t}, J_{\mathrm{CF}}=25.9 \mathrm{~Hz}\right), 69.7(\mathrm{t}), 74.8(\mathrm{t}), 94.1(\mathrm{~s}), 115.8\right.$ $\left(\mathrm{tt}, J_{\mathrm{CF}}=253.1 \mathrm{~Hz}, J_{\mathrm{CF}}^{\prime}=29.3 \mathrm{~Hz}\right), 115.9\left(\mathrm{tt}, J_{\mathrm{CF}}=254.5 \mathrm{~Hz}, J_{\mathrm{CF}}^{\prime}=29.7 \mathrm{~Hz}\right), 120.6(\mathrm{~d}), 137.5$ (d), 156.7 (s); ${ }^{19} \mathrm{~F}$ NMR $\left(\mathrm{CDCl}_{3}\right) \delta$-122.8, -122.2. Anal. Calcd for $\mathrm{C}_{30} \mathrm{H}_{33} \mathrm{~F}_{8} \mathrm{NO}_{5}: \mathrm{C}, 56.34 ; \mathrm{H}$, 5.20. Found: C, 56.41; H, 5.13. CI-HRMS Calcd for $\mathrm{C}_{30} \mathrm{H}_{33} \mathrm{~F}_{8} \mathrm{NO}_{5}$ : $[\mathrm{Mr}+\mathrm{H}]^{+} \mathrm{m} / \mathrm{z}$ 640.2309. Found: $\mathrm{m} / \mathrm{z}$ 640.2316. The structure of 7 has been established unequivocally via application of Xray crystallographic methods (vide infra).

Preparation of 9. A suspension of $\mathrm{NaH}(180 \mathrm{mg}$ of a $60 \%$ suspension of $\mathrm{NaH}$ in mineral oil, $4.49 \mathrm{mmol})$ in dry THF $(25 \mathrm{~mL})$ under argon was cooled to $0{ }^{\circ} \mathrm{C}$ via application of an external ice-water bath. To this cooled solution was added dropwise with stirring a solution of 5 (826 mg, $1.50 \mathrm{mmol})$ in dry THF $(25 \mathrm{~mL})$ under argon during $1 \mathrm{~h}$. After the addition of 5 had been completed, the external ice-water bath was removed, and the reaction mixture was allowed to warm gradually to ambient temperature while stirring during $1 \mathrm{~h}$. The reaction mixture then was heated to reflux temperature, and a solution of 2,6-bis(bromomethyl)-1-fluorobenzene (8, ${ }^{15} 422$ $\mathrm{mg}, 1.50 \mathrm{mmol})$ in dry THF $(125 \mathrm{~mL})$ was added dropwise with stirring during $12 \mathrm{~h}$. The resulting mixture was refluxed during 4 days, at which time the reaction mixture was cooled to 0 ${ }^{\circ} \mathrm{C}$ via application of an external ice-water bath, and the reaction was quenched via careful, dropwise addition of cold water $(1 \mathrm{~mL})$ with stirring. The resulting mixture was concentrated in vacuo, and the residue was extracted into EtOAc $(150 \mathrm{~mL})$. The organic phase was washed sequentially with water $(70 \mathrm{~mL})$ and brine $(80 \mathrm{~mL})$, dried $\left(\mathrm{MgSO}_{4}\right)$, and filtered, and the filtrate was concentrated in vacuo. The residue was purified via column chromatography on silica gel by eluting with 25\% EtOAc-hexane. Pure 9 (609 mg, 62\%) was thereby obtained as a viscous oil; IR (film): 2930 (s), 2845 (s), 1605 (w), 1572 (w), 1445 (s), 1105 (vs), 742 (s), $655 \mathrm{~cm}^{-1}$ (m); ${ }^{1} \mathrm{H}$ $\operatorname{NMR}\left(\mathrm{CDCl}_{3}\right) \delta 1.48\left(\mathrm{AB}, J_{\mathrm{AB}}=10.3 \mathrm{~Hz}, 1 \mathrm{H}\right), 1.81\left(\mathrm{AB}, J_{\mathrm{AB}}=10.3 \mathrm{~Hz}, 1 \mathrm{H}\right), 1.98(\mathrm{t}, J=6.2 \mathrm{~Hz}$, $4 \mathrm{H}), 2.26-2.62(\mathrm{~m}, 8 \mathrm{H}), 3.50-3.68(\mathrm{~m}, 4 \mathrm{H}), 3.77$ (t, $J=14.0 \mathrm{~Hz}, 4 \mathrm{H}), 3.93$ (t, $J=14.2 \mathrm{~Hz}, 4$ $\mathrm{H}), 4.69(\mathrm{~s}, 4 \mathrm{H}), 7.14(\mathrm{t}, J=7.0 \mathrm{~Hz}, 1 \mathrm{H}), 7.36(\mathrm{t}, J=6.9 \mathrm{~Hz}, 2 \mathrm{H}) ;{ }^{13} \mathrm{C} \mathrm{NMR}\left(\mathrm{CDCl}_{3}\right) \delta 32.3(\mathrm{t})$, $41.5(\mathrm{~d}), 43.4(\mathrm{t}), 44.2(\mathrm{~d}), 48.2(\mathrm{~d}), 58.8(\mathrm{~d}), 67.6\left(\mathrm{t}, J_{\mathrm{CF}}=25.2 \mathrm{~Hz}\right), 67.8(\mathrm{t}), 68.2\left(\mathrm{t}, J_{\mathrm{CF}}=25.1\right.$ $\mathrm{Hz}), 69.6(\mathrm{t}), 94.0(\mathrm{~s}), 115.8\left(\mathrm{tt}, J_{\mathrm{CF}}=252.6 \mathrm{~Hz}, J_{\mathrm{CF}}^{\prime}=29.0 \mathrm{~Hz}\right), 116.0\left(\mathrm{tt}, J_{\mathrm{CF}}=253.3 \mathrm{~Hz}, J_{\mathrm{CF}}^{\prime}=\right.$ $29.1 \mathrm{~Hz}), 124.1\left(\mathrm{~d}, J_{\mathrm{CF}}=13.0 \mathrm{~Hz}\right), 124.3\left(\mathrm{~d}, J_{\mathrm{CF}}=2.3 \mathrm{~Hz}\right), 130.5\left(\mathrm{~d}, J_{\mathrm{CF}}=4.4 \mathrm{~Hz}\right), 158.9\left(\mathrm{~d}, J_{\mathrm{CF}}=\right.$ $247.7 \mathrm{~Hz}$ ). CI-HRMS Calcd for $\mathrm{C}_{31} \mathrm{H}_{33} \mathrm{~F}_{9} \mathrm{O}_{5}:[\mathrm{Mr}+\mathrm{H}]^{+} \mathrm{m} / \mathrm{z}$ 657.22625. Found: $\mathrm{m} / \mathrm{z}$ 657.22635.

X-Ray structure of 7. All data were collected at 293(2) $\mathrm{K}$ on a Brucker SMART ${ }^{\mathrm{TM}} 1000 \mathrm{CCD}$ diffractometer. The frames were integrated with the SAINT program package ${ }^{18}$ by using a narrow frame algorithm. The structure was solved and refined by using SHELXTL. ${ }^{19}$ There is 
some disorder associated with the orientation of the methylene group on the cage moiety and with the side-chain, particularly in the vicinity of the $\mathrm{CF}_{2}$ groups. This disorder was not pursued further, since the primary intent of this analysis was structural confirmation. The structure was verified by using PLATON. ${ }^{20}$ Crystal and refinement data are given in Table 2.

Table 2. X-ray data crystal and structure refinement data for 7

\begin{tabular}{cc}
\hline Compound & 7 \\
\hline Formula & C35H33F8NO5 \\
Size $(\mathrm{mm})$ & $0.32 \propto 0.23 \infty 0.18$ \\
Space Group & $\mathrm{P}-1$ \\
$\mathrm{a}(\AA)$ & $10.2246(8)$ \\
$\mathrm{b}(\AA)$ & $12.4036(10)$ \\
$\mathrm{c}(\AA)$ & $13.2086(11)$ \\
$\alpha\left(^{\circ}\right)$ & $111.779(2)$ \\
$\beta\left(^{\circ}\right)$ & $102.583(2)$ \\
$\gamma\left(^{\circ}\right)$ & $98.051(2)$ \\
$\mathrm{V}(\AA)$ & $1472.4(2)$ \\
$\mathrm{Z}$-value & 2 \\
Dcalc $(\mathrm{g}-\mathrm{cm}-3)$ & 1.443 \\
$\mu(\mathrm{mm}-1)$ & 0.130 \\
$\mathrm{~T}(\mathrm{~K})$ & $293(2)$ \\
20range $\left({ }^{\circ}\right)$ & 1.74 to 22.50 \\
Total reflections & 8765 \\
Independent reflections & 3844 \\
Rint & 0.0660 \\
Data/restraints/ & $3844 / 0 / 398$ \\
parameters & \\
$\mathrm{R}, \mathrm{R}($ all $)$ & $0.0963,0.1481$ \\
GOF & 1.134 \\
Extinction correction & $0.000(4)$ \\
\hline
\end{tabular}

\section{Acknowledgments}

We thank the Robert A. Welch Foundation [Grants B-0963 (A. P. M), P-074 (W. H. W.)], the Texas Advanced Technology Program (Grant 003659-02060-1999, to A. P. M.), and the U. S. Department of Energy (Grant DE-FG07-98ER14936, to A. P. M.) for financial support of this study. In addition, we thank Professor Jennifer S. Brodbelt (Department of Chemistry, University 
of Texas at Austin) for having kindly obtained high-resolution chemical ionization mass spectral data for all new compounds reported herein.

\section{References and Notes}

1. Pedersen, C. J. J. Am. Chem. Soc. 1967, 89, 2495.

2. Pedersen, C. J. J. Am. Chem. Soc. 1970, 92, 391.

3. (a) Fenton, D. E. Chem. Soc. Rev. 1977, 6, 325. (b) Dockex, J. Synthesis 1973, 441. (c) Gokel, G. W.; Durst, H. D. Synthesis 1976, 168.

4. Murray-Rust, P.; Stallings, W. C.; Monti, C. T.; Prestone, R. K.; Glusker, J. P. J. Am. Chem. Soc. 1983, 105, 3206.

5. (a) See: Plenio, H. Chem. Rev. 1997, 97, 3363 and references cited therein. (b) Takemura, H.; Nakashima, S.; Kon, N.; Inazu, T. Tetrahedron Lett. 2000, 41, 6105. (c) Takemura, H.; Kon, N.; Kotoku, M.; Nakashima, S.; Otsuka, K.; Yasutake, M.; Shinmyozu, T.; Inazu, T. J. Org. Chem. 2001, 66, 2778.

6. Harder, S.; Streitwieser, A.; Petty, J. T.; Schleyer, P. von R. J. Am. Chem. Soc. 1995, 117, 3253.

7. (a) Bergstrom, D. E.; Swarling, D. J. Fluorine-Containing Molecules: Structure, Reactivity, Synthesis and Applications; VCH: Weinheim, 1988. (b) Liebman, J. F.; Greenberg, A.; Dolbier, W. R. Fluorine-Containing Molecules, VCH: Weinheim, 1988.

8. Plenio, H.; Diodone, R.; Badura, D. Angew. Chem., Int. Ed. 1997, 36, 156.

9. See: Marchand, A. P.; Kumar, K. A.; McKim, A. S.; Alihodzic, S.; Chong, H.-S.; Krishnudu, K.; Takhi, M.; Mlinaric-Majerski, K.; Kragol, G.; Sumanovac, T. Kem. Ind. 2001, 50, 129 and references cited therein.

10. Marchand, A. P.; Alihodzic, S.; McKim, A. S.; Kumar, K. A.; Mlinaric-Majerski, K.; Sumanovac, T.; Bott, S. G. Tetrahedron Lett. 1998, 39, 1861.

11. (a) Haddadin, M. J.; Wang, Y.; Frenkel, S.; Bott, S. G.; Yang, L.; Braterman, P. S.; Carvallo, C.; Marchand, A. P.; Watson, W. H.; Kashyap, R. P.; Krawiec, M.; Bourne, S. A. Heterocycles 1994, 37, 869. (h) Bartsch, R. A.; Eley, M.; Marchand, A. P.; Shukla, R.; Kumar, K. A.; Tetrahedron 1996, 52, 8979.

12. Macias, A. T.; Kumar, K. A.; Marchand, A. P.; Evanseck, J. D. J. Org. Chem. 2000, 65, 2083. (b) Castro, R.; Davidov, P. D.; Kumar, K. A.; Marchand, A. P.; Evanseck, J. D.; Kaifer, A. E. J. Phys. Org. Chem. 1997, 10, 369.

13. Marchand, A. P.; Cal, D.; Mlinaric-Majerski, K.; Vinkovic, M.; Ejsmont, K.; Watson, W. H. J. Chem. Crystallogr. Manuscript submitted (2002).

14. Baker, W.; Buggle, K.M.; McOmie, J.F.W.; Watkins, D.A.M. J. Chem. Soc. 1958, 3594.

15. Nasir, M.S.; Cohen, B.I.; Karlin, K.D. J. Am. Chem. Soc. 1992, 114, 2482.

16. (a) Ouchi, M.; Inoue, Y.; Wada, K.; Iketani, S.; Hakushi, T.; Weber, E. J. Org. Chem. 1987, 52, 2420. (b) Bartsch, R. A.; Eley, M. D.; Marchand, A. P.; Shukla, R.; Kumar, K. A.; 
Reddy G. M. Tetrahedron 1996, 52, 8979. (c) Marchand, A. P.; Kumar, K. A.; McKim, A.S. Tetrahedron 1997, 53, 3467.

17. Marchand, A. P.; Chong, H. S.; Alihodzic, S.; Watson, W. H.; Bodige, S. G. Tetrahedron 1999, 55, 9687.

18. SAINT, ${ }^{\mathrm{TM}}$ Version 6.02. Bruker Analytical X-ray Systems, Inc., Copyright 1997-1999.

19. SHELXTL, Version 5.1. Bruker Analytical X-ray Systems, Inc., Copyright 1998.

20. Speck, A. L. PLATON - A Multipurpose Crystallographic Tool, University of Utrecht, The Netherlands, 2001. 